\title{
Circumpolar genetic population structure of capelin Mallotus villosus
}

\author{
K. Præbel*, J. I. Westgaard, S. E. Fevolden, J. S. Christiansen \\ Department of Aquatic Biosciences, Norwegian College of Fishery Science, University of Tromsø, 9037 Tromsø, Norway
}

\begin{abstract}
Capelin Mallotus villosus is the most abundant pelagic fish species in boreal and subarctic waters. The ecological and commercial importance of capelin emphasizes the need for a better understanding of the genetic population structure of the species and the mechanisms underlying its population dynamics. With this aim, 1155 capelin from the entire distributional range of the species were genotyped using 9 recently-developed microsatellite markers. The genetic analyses clearly demonstrated that the circumpolar capelin population can be divided into 4 regional groups: (1) West Pacific, (2) East Pacific, (3) Newfoundland, and (4) Northeast Atlantic and West Greenland. Highly significant genetic differentiation was observed between capelin from the western and eastern Pacific, and a high assignment success within both regions indicated minimal gene flow between these populations. Within the Atlantic Ocean, the Newfoundland population was differentiated from all the other samples. Among the remaining samples within the Atlantic Ocean the microsatellite data were less conclusive. Comparison of our results with studies of species with similar distribution, duration of planktonic stages and dispersal capacity suggests that genetic structuring of capelin within the complex system of the Northeast Atlantic Ocean cannot be ruled out.
\end{abstract}

KEY WORDS: Mallotus villosus $\cdot$ Population structure $\cdot$ Genetic differentiation · Microsatellite markers

\section{INTRODUCTION}

The capelin Mallotus villosus (Müller, 1776) is one of the most abundant fish species in the sub-arctic ecosystem. It plays a key role as an intermediary in energy conservation from production at lower (zooplankton) to higher trophic levels, e.g. whales, seals, birds and other fish species (Wassmann et al. 2006). It is, furthermore, important for commercial fisheries in the Atlantic Ocean, with annual landings of $0.8-2.1 \times$ $10^{6} \mathrm{t}$, whereas landings in the Pacific Ocean are considerable smaller ( $\leq 4000$ t, Carscadden \& Vilhjálmsson 2002).

Capelin is widespread throughout the sub-arctic regions of the Pacific and Atlantic Oceans and it is rare along the Arctic coasts of Russia and Canada. For reviews of the distribution and general ecology of capelin, we refer to Stergiou (1989), Gjøsæter (1998) and Vilhjálmsson (2002). The marginal distribution of capelin towards high latitudes is governed by sub- arctic water circulations (Dunbar 1983). Hence, Stergiou (1989) attributed the discontinuous pattern of capelin populations within the Arctic Ocean to survival of relicts from warmer periods in the past. In this regard, it is of note that rising sea temperatures will enhance the dispersal and mixture of capelin populations in the Arctic Ocean, as has been observed within the Pacific Ocean and the Barents Sea (Naumenko 1996, Gjøsæter 1998). Like other members of the Osmeridae, capelin may undertake extensive spawning and feeding migrations (Gjøsæeter 1998, Vilhjálmsson 2002). Inshore capelin, e.g. capelin from Norwegian fjords, West Greenland and Alaska, spend most of their lives within a limited geographical area (Brown 2002, Friis-Rødel \& Kanneworff 2002). Whether these populations are reproductively isolated is not yet known. Capelin displays one of 2 alternative reproductive modes; it spawns on the substratum either on the beach or in deeper oceanic water (Carscadden et al. 1989, Stergiou 1989). The ocean-spawning capelin 
appear to be strictly semelparous (i.e. both sexes die after a single reproductive event), whereas beachspawning capelin are both semelparous and iteroparous (i.e. death after 2 or more reproductive events) (Christiansen \& Siikavuopio 1998, Gjøsæter 1998). After hatching, the larval drift is directed by ocean and wind-induced surface currents (Gjøsæter 1998). The immature ocean capelin often migrate long distances to find suitable feeding grounds, whereas local populations complete their entire life cycle in nearshore waters and fjords (Brown 2002, Friis-Rødel \& Kanneworff 2002, Vilhjálmsson 2002). Thus, it is first and foremost the larval and immature stages of capelin that have high potential for dispersal, though mature capelin may also undertake spawning migrations across vast geographical distances, e.g. the Barents Sea capelin (Behrens et al. 2006).

Understanding of the circumpolar genetic population structure of capelin is as yet fragmentary. The genetic relationship of capelin populations within the Pacific Ocean and between the Pacific and Atlantic Oceans has not been investigated previously. Within the Atlantic Ocean, the Newfoundland capelin can be genetically discriminated from capelin in western Greenland (Payne 1976), Iceland (Dodson et al. 1991), and the Barents Sea (Dodson et al. 1991, Birt et al. 1995, Røed et al. 2003). Previous studies have failed to resolve the genetic structuring of capelin on smaller geographical scales, e.g. genetic differentiation of Barents Sea capelin from a local fjord population (Balsfjord) (Mork \& Friis-Sörensen 1983) and between ocean and beach spawning capelin from Newfoundland (Dodson et al. 1991). However, Roby et al. (1991) showed that capelin in the St. Lawrence estuary and Gulf of St. Lawrence (eastern Canada) could be differentiated into eastern and western populations using a combination of morphometric and genetic methods.

The ecological and economical importance of capelin clearly emphasizes the need for a better understanding of the genetic population structure of the species and the mechanisms underlying its population dynamics. Whereas previous studies on population genetics of capelin have used polymorphic proteins (allozymes) (Payne 1976, Mork \& Friis-Sörensen 1983, Sørensen \& Simonsen 1988, Roby et al. 1991) and mtDNA as genetic markers (Dodson et al. 1991, Birt et al. 1995), a set of di- and tetranucleotide microsatellite DNA markers has recently been developed for capelin population discrimination (Røed et al. 2003, Gordos et al. 2005). The advantage of microsatellite markers compared to other genetic markers is that they are putatively neutral and highly polymorphic, their codominant alleles are easy to score, and they provide more informative results than other markers (cf. e.g. Sunnucks 2000). Here, we employ a selected set of the new microsatellite markers to examine the genetic population structure of capelin over its entire distributional range.

\section{MATERIALS AND METHODS}

Sample collection. A total of 1155 capelin was analysed from 16 locations throughout the species' distributional range (Table 1). The fish were collected by trawling or shore seine. The samples consisted of the heads, which were preserved in $96 \%$ ethanol, or of whole specimens preserved frozen at $-80^{\circ} \mathrm{C}$. Alaskan capelin (ALA, Table 1) was collected from several trawl hauls within the Shelikof Strait off the Alaska Peninsula. The trawl samples were pooled on board the ship. Two samples of capelin were obtained from the Northwest Pacific (Aniva Bay); one was collected at a spawning beach, the other by pelagic trawling off the coast of Aniva Bay. Samples were collected mainly at or near spawning grounds and comprised exclusively mature specimens. Capelin from Porsangerfjorden, North Norway (POR) and Jan Mayen, Greenland Sea (JMA and JMB) were sampled off the spawning grounds, but specimens were still adult individuals. Samples from Aniva Bay (ABA), Alaska (ALA), and Isfjorden, Svalbard (IFJ) were mixtures of mature and immature individuals. The sampling aimed at including a minimum of 50 specimens from each location. However, one sample from Jan Mayen (JMA), one from Newfoundland (Middle Cove, NFO), and the West Greenland (WGR) sample contained only 43, 31, and 48 specimens, respectively.

DNA extraction and microsatellite amplification. DNA was extracted from 1 to 3 gill arches using the Proteinase K/salt-extraction protocol of Fevolden \& Pogson (1997). A total of 13 microsatellite loci was arranged in 3 multiplex reactions (Table 2) using a reaction volume of $10 \mu \mathrm{l}$. The amplifications of the microsatellite loci were performed by polymerase chain reaction (PCR) using a GeneAmp 2700 thermal cycler (Applied Biosystems). The PCR contained 20 to $50 \mathrm{ng}$ of template DNA, $1 \times$ PCR buffer $(50 \mathrm{mM} \mathrm{KCl}$ and

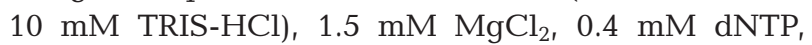
0.075 to $5.0 \mu \mathrm{M}$ of each primer (Table 2), and $1 \mathrm{U}$ AmpliTaq DNA polymerase (Applied Biosystems). The PCR profiles were identical for the 3 multiplexes and consisted of an initial denaturation step at $95^{\circ} \mathrm{C}$ for $10 \mathrm{~min}$, followed by 40 cycles of $95^{\circ} \mathrm{C}$ for $20 \mathrm{~s}, 56^{\circ} \mathrm{C}$ for $30 \mathrm{~s}$, and $72^{\circ} \mathrm{C}$ for $1 \mathrm{~min}$, followed by a final elongation step of $10 \mathrm{~min}$ at $72^{\circ} \mathrm{C}$. PCR products were mixed with deionised formamide/GeneScan 500-LIZ size standard (Applied Biosystems) and separated using an ABI 3100 automated sequencer (Applied Biosystems). The alleles were scored using the software GeneMapper 
3.7 (Applied Biosystems). Each genotype was scored twice by visual inspection and if inconsistency occurred, a second person performed the scoring.

The software MICRO-CHECKER 2.2.3 (Van Oosterhout et al. 2004) was used to identify possible null alleles, large allele drop-out, scoring of stuttering peaks and possible typographic errors. The analysis indicated that null alleles may be present at the loci Mvi2, 22 and 31 and these were, therefore, omitted from further analyses. No other loci showed signs of possible null alleles. The locus Mvi3 was excluded from the data analysis due to poor amplification success. All other loci had high amplification and scoring success (97 to $99 \%$ ) (Table 2).

Data analysis. Samples from the same geographical area that showed non-significant genetic discrepancy were pooled to increase the statistical power (see 'Results'). Basic statistics such as observed and expected heterozygosity, inbreeding coefficients, departures from Hardy-Weinberg equilibrium for each locus

Table 1. Mallotus villosus. Details of 16 samples. Samples from the same area showing no genetic divergence were pooled, so that a total of 12 samples was included in the statistical processing. Pooled samples are numbered in the furthest left column. Code refers to sample abbreviation used in text. Dates are day/month-year

\begin{tabular}{|c|c|c|c|c|c|c|c|c|}
\hline & Locality & $\begin{array}{c}\text { General } \\
\text { area }\end{array}$ & Code & $\begin{array}{l}\text { Sampling } \\
\text { device }\end{array}$ & $\mathrm{N}$ & Latitude & Longitude & $\begin{array}{c}\text { Sample } \\
\text { date }\end{array}$ \\
\hline \multirow[t]{2}{*}{1} & Aniva Bay, Sakhalin & NW Pacific & \multirow[t]{2}{*}{ ABA } & Shore seine & 55 & $\mathrm{~N} 46^{\circ} 35^{\prime}$ & $\mathrm{E} 143^{\circ} 10^{\prime}$ & $11 / 6-2003$ \\
\hline & Aniva Bay, Sakhalin ${ }^{\mathrm{a}}$ & NW Pacific & & Pelagic trawl & 48 & $\mathrm{~N} 46^{\circ} 09^{\prime}$ & $\mathrm{E} 143^{\circ} 20^{\prime}$ & 29/6-2003 \\
\hline 2 & Alaska Peninsula, Alaska ${ }^{a, b}$ & NE Pacific & ALA & Pelagic trawl & 96 & $\mathrm{~N} 55^{\circ} 32^{\prime}$ & $\mathrm{W} 158^{\circ} 02^{\prime}$ & $14 / 9-2003$ \\
\hline \multirow[t]{2}{*}{3} & Bellevue Beach, Newfoundland & NW Atlantic & \multirow[t]{2}{*}{$\mathrm{NFO}$} & Shore seine & 49 & $\mathrm{~N} 47^{\circ} 38^{\prime}$ & W053 $45^{\prime}$ & Jul 2000 \\
\hline & Middle Cove, Newfoundland & NW Atlantic & & Shore seine & 31 & $\mathrm{~N} 47^{\circ} 39^{\prime}$ & $\mathrm{W} 052^{\circ} 42^{\prime}$ & Jul 2000 \\
\hline 4 & Sarfanguaq, West-Greenland & NW Atlantic & WGR & Shore seine & 48 & $\mathrm{~N} 66^{\circ} 55^{\prime}$ & W052 $59^{\prime}$ & Jun 2003 \\
\hline 5 & Jan Mayen, Greenland Sea & NE Atlantic & JMA & Bottom trawl & 43 & N7 $70^{\circ} 54^{\prime}$ & W008 $04^{\prime}$ & $17 / 2-2001$ \\
\hline 6 & Jan Mayen, Greenland Sea & NE Atlantic & JMB & Bottom trawl & 59 & $\mathrm{~N} 70^{\circ} 35^{\prime}$ & W008 $21^{\prime}$ & $3 / 3-2001$ \\
\hline 7 & Isfjorden, Svalbard ${ }^{a}$ & NE Atlantic & IFJ & Bottom trawl & 96 & N77 $52^{\prime}$ & $\mathrm{E} 010^{\circ} 15^{\prime}$ & $2 / 8-2000$ \\
\hline \multirow[t]{3}{*}{8} & Ingøy dypet, West Barents Sea & NE Atlantic & \multirow[t]{3}{*}{ BSW } & Pelagic trawl & 80 & N71 $1^{\circ} 37^{\prime}$ & $\mathrm{E} 022^{\circ} 25^{\prime}$ & $25 / 2-2003$ \\
\hline & Hjelmsøy, West Barents Sea & NE Atlantic & & Pelagic trawl & 111 & $\mathrm{~N} 71^{\circ} 10^{\prime}$ & $\mathrm{E} 024^{\circ} 49^{\prime}$ & $17 / 3-2004$ \\
\hline & Nordkap, Barents Sea & NE Atlantic & & Pelagic trawl & 96 & $\mathrm{~N} 71^{\circ} 12^{\prime}$ & $\mathrm{E} 025^{\circ} 34^{\prime}$ & $17 / 3-2004$ \\
\hline 9 & Vardø, East Barents Sea & NE Atlantic & BSE & Pelagic trawl & 96 & N70 $10^{\prime}$ & $\mathrm{E} 031^{\circ} 14^{\prime}$ & $10 / 3-2005$ \\
\hline 10 & Porsangerfjorden, Barents Sea & NE Atlantic & POR & Bottom trawl & 101 & $\mathrm{~N} 70^{\circ} 07^{\prime}$ & $\mathrm{E} 025^{\circ} 09^{\prime}$ & $4 / 10-2000$ \\
\hline 11 & Varangerfjorden, East Barents Sea & NE Atlantic & VAR & Bottom trawl & 50 & N70 $07^{\prime}$ & $\mathrm{E} 028^{\circ} 38^{\prime}$ & 10/3-1999 \\
\hline 12 & Balsfjorden, North Norway & NE Atlantic & BFJ & Pelagic trawl & 96 & $\mathrm{~N} 69^{\circ} 24^{\prime}$ & $\mathrm{E} 019^{\circ} 02^{\prime}$ & $30 / 3-2004$ \\
\hline
\end{tabular}

Table 2. Mallotus villosus. Details and standard diversity estimates for the various loci used. GenBank: accession number; Mplx: multiplex; C: concentration of primer in multiplex; S: amplification success; S-R: observed size range (number of base pairs) of the loci; $A$ : number of observed alleles; $H_{\mathrm{e}}$ : expected heterozygosity; $F_{\mathrm{is}}$ : inbreeding coefficient; $F_{\mathrm{ST}}$ : fixation index; $R_{S T}$ : observed sum of squared size difference; $\rho R_{S T}$ : permutated $R_{S T}$ with $95 \%$ confidence interval (CI). Asterisks indicate significance level for the permutation test and for the overall $F_{\mathrm{ST}}$ estimates $\left({ }^{*} \mathrm{p}<0.05 ;{ }^{* *} \mathrm{p}<0.01 ;{ }^{* * *} \mathrm{p}<0.001\right)$

\begin{tabular}{|lllllllllllllll|}
\hline Locus & GenBank & Mplx & C $(\mu \mathrm{M})$ & Label & S (\%) & S-R (bp) & \multicolumn{1}{c}{$A$} & $H_{\mathrm{e}}$ & $F_{\text {is }}$ & $F_{\mathrm{ST}}$ & & $R_{S T}$ & $\rho R_{S T}(\mathrm{CI})$ \\
\hline Mav-9 & AY-291351 & A & 0.2 & 6-FAM & 98 & $150-290$ & 61 & 0.952 & 0.053 & $0.0061^{* * *}$ & $0.0173^{*}$ & $0.0057(-0.0020-0.0175)$ \\
Mav-17 & AY-291353 & B & 5.0 & PET & 99 & $190-236$ & 22 & 0.759 & 0.077 & $0.0552^{* * *}$ & 0.0707 & $0.0513(0.0005-0.1812)$ \\
Mav-38 & AY-291355 & B & 0.5 & 6-FAM & 99 & $125-175$ & 26 & 0.844 & 0.038 & $0.0283^{* * *}$ & 0.0384 & $0.0274(0.0060-0.0595)$ \\
Mav-42 & AY-291356 & A & 0.1 & NED & 98 & $102-132$ & 16 & 0.588 & 0.073 & $0.0264^{* * *}$ & 0.0406 & $0.0230(0.0004-0.0547)$ \\
Mav-51 & AY-291357 & B & 5.0 & NED & 98 & $144-212$ & 28 & 0.735 & 0.151 & $0.0213^{* * *}$ & 0.0059 & $0.0186(-0.0012-0.0555)$ \\
Mav-62 & AY-291360 & B & 0.75 & PET & 99 & $109-171$ & 31 & 0.899 & 0.028 & $0.0060^{* * *}$ & $0.0210^{* *}$ & $0.0057(-0.0015-0.0158)$ \\
Mav-81 & AY-291361 & B & 0.63 & VIC & 99 & $116-132$ & 8 & 0.333 & 0.128 & $0.1654^{* * *}$ & 0.1289 & $0.2018(0.0417-0.5192)$ \\
Mav-135 & AY-291365 & A & 0.075 & 6-FAM & 99 & $85-121$ & 19 & 0.787 & 0.098 & $0.0837^{* * *}$ & 0.1741 & $0.0799(0.0054-0.2255)$ \\
Mvi5 & AY-686623 & A & 0.7 & PET & 97 & $82-142$ & 16 & 0.828 & 0.072 & $0.0362^{* * *}$ & $0.1234^{*}$ & $0.0361(0.0029-0.1102)$ \\
\hline
\end{tabular}


and sample and tests for linkage disequilibrium were calculated with GENEPOP 3.4 software (Raymond \& Rousset 1995). The number of alleles per locus and average number of alleles and private alleles per sample were estimated using HP-RARE 1.0 software (Kalinowski 2005). The rarefaction procedure implemented in the software was utilised for allelic estimates in the samples. This procedure corrects for different sample sizes and the estimation was standardised using the smallest sample (80 genes). In order to determine the appropriate evolutionary model for describing genetic differentiation (IAM [infinite-alleles model] versus SMM [stepwise mutation model]), an allele permutation test was performed as implemented by SPAGeDi software (Hardy \& Vekemans 2002) using 10000 permutations. Pairwise $F_{\mathrm{ST}}$ values (Weir \& Cockerham 1984) between all samples were estimated and tested for statistical significance (10000 permutations) using ARLEQUIN 3.01 software (Excoffier et al. 2005). Sequential Bonferroni corrections were applied in all multiple comparisons following Rice (1989). Two different methods were used to assess the power of the statistical tests for population differentiation, an approach similar to that used by Paetkau et al. (2004) and the procedure of Ryman \& Palm (2006). Both methods revealed power values close to $1(\geq 0.94$; details on data processing available from the authors on request), providing strong support for the heterogeneity observed.

An assignment test was used to estimate scoring success within samples using GENECLASS 2.0 software (Piry et al. 2004). Assignment success was calculated as the proportion of self-assigned individuals within each sample. Principal component analysis (PCA) performed by the software PCA-GEN 1.2.1 (available at: www2.unil.ch/popgen/softwares/pcagen.htm) was used to visualize the genetic structuring among samples. To estimate the assumed grouping of samples, 30 independent runs assuming number of populations $(K)$ from 2 to 6 were performed by STRUCTURE software (Pritchard et al. 2000). The most likely (highest ln $\operatorname{Pr}[X \mid K]$ ) grouping was tested using pairwise non-parametric Wilcoxon signed rank statistics applying 10000 Monte Carlo simulations to obtain the significance. This information was utilised in a spatial analysis of the molecular variance (SAMOVA) (Dupanloup et al. 2002) using $F_{\mathrm{ST}}$ as distance measure and 100 initial conditions. The geographic positions used were those listed in Table 1, except for the pooled stations for which mean geographic positions were calculated for each pooled sample. To overcome the geometric problems that arise when employing circumpolar geographical positions we plotted the sample positions onto a map and drew a coordinate system upon it. Then new arbitrary coordinates were obtained and utilised in the SAMOVA analysis and in the subse- quent identification of possible barriers $(K=4)$ to gene flow. Computation of barriers was performed by BARRIER 2.2 software (Manni et al. 2004), first using the multi-locus $F_{\mathrm{ST}}$ matrix, and subsequently by calculating $F_{\mathrm{ST}}$ matrices for the 9 loci separately to obtain 'consensus barriers'.

\section{RESULTS}

\section{Standard genetic measures}

The allele permutation test showed that for 3 of the 9 loci, the observed $R_{S T}$ values were significantly higher than expected (Table 2). The IAM-based $F_{\mathrm{ST}}$ estimator was therefore used for pairwise population comparisons. The 16 samples were compared pairwise by $F_{\mathrm{ST}}$, and samples from the same geographical localities that showed non-significant genetic differences were pooled to increase statistical power in the subsequent analyses. The pooled samples were the 2 from Aniva Bay $\left(F_{\mathrm{ST}}=0.0059, \mathrm{p}=0.0187\right.$, non-significant after correction for multiple tests), the 2 from Newfoundland $\left(F_{\mathrm{ST}}=0.0001, \mathrm{p}=0.5834\right)$, and 3 from the western Barents Sea (BS_A/BS_B: $F_{\mathrm{ST}}=-0.0016, \mathrm{p}=0.9476$; BS_A/BS_C: $F_{\mathrm{ST}}=-0.0012, \mathrm{p}=0.8834 ;$ BS_B/BS_C: $F_{\mathrm{ST}}=0.0005, \mathrm{p}=0.3614$ ) (see Table 1). A new pairwise $F_{\mathrm{ST}}$ matrix was then calculated for the 12 pooled samples (Table 3).

Standard genetic estimates such as average number of alleles and private alleles, expected heterozygosities and the inbreeding coefficient for each sample are summarised in Table 4. Highest average numbers of private alleles per sample were found in ALA (0.7), BFJ (0.5), and WGR/BSE (0.4). Of 108 tests, 9 showed departures from the Hardy-Weinberg equilibrium, which is slightly above what is expected by chance. Observed number of alleles, allele size range, expected heterozygosity and variability observed for each locus across all samples are shown in Table 2. The overall estimates of $F_{\text {ST }}$ per locus were in general high (0.0213 to 0.1654), with the exception of Mav-9 $\left(F_{\mathrm{ST}}=0.0061\right)$ and Mav-62 $\left(F_{\mathrm{ST}}=0.0060\right)$. All estimates were highly significant (Table 2). The test for linkage disequilibrium revealed that 2 out of 432 tests demonstrated possible linkage, which is well within what is expected by chance.

\section{Circumpolar genetic structure of capelin}

The Pacific Ocean samples (ABA and ALA) displayed relatively strong and highly significant genetic divergence (Table 3). Each of them seems clearly distinguished from samples within the Atlantic Ocean 
Table 3. Mallotus villosus. Pairwise $F_{\mathrm{ST}}$ values between the samples included in the study (sample codes in Table 1). Significance level has been adjusted using sequential Bonferroni correction (Rice 1989). ${ }^{*} \mathrm{p}<0.05 ;{ }^{* *} \mathrm{p}<0.01 ;{ }^{* * *} \mathrm{p}<0.001$

\begin{tabular}{|c|c|c|c|c|c|c|c|c|c|c|c|}
\hline & $\mathrm{ABA}$ & ALA & BFJ & BSE & BSW & IFJ & JMA & $\mathrm{JMB}$ & NFO & POR & VAR \\
\hline ALA & $0.039^{* * *}$ & - & & & & & & & & & \\
\hline BFJ & $0.065^{* * *}$ & $0.082^{* * *}$ & - & & & & & & & & \\
\hline BSE & $0.064^{* * *}$ & $0.079^{* * *}$ & 0.001 & - & & & & & & & \\
\hline BSW & $0.055^{* * *}$ & $0.075^{* * *}$ & 0.002 & 0.002 & - & & & & & & \\
\hline IFJ & $0.071^{* * *}$ & $0.096^{* * *}$ & $0.009^{* *}$ & $0.009^{* * *}$ & $0.009^{* * *}$ & - & & & & & \\
\hline JMA & $0.061^{* * *}$ & $0.083^{* * *}$ & $0.026^{* * *}$ & $0.024^{* * *}$ & $0.021^{* * *}$ & $0.018^{* * *}$ & - & & & & \\
\hline JMB & $0.056^{* * *}$ & $0.069^{* * *}$ & 0.002 & 0.001 & 0.004 & $0.008^{* *}$ & $0.025^{* * *}$ & - & & & \\
\hline NFO & $0.113^{* * *}$ & $0.113^{* * *}$ & $0.074^{* * *}$ & $0.069^{* * *}$ & $0.079^{* * *}$ & $0.094^{* * *}$ & $0.103^{* * *}$ & $0.073^{* * *}$ & - & & \\
\hline POR & $0.059^{* * *}$ & $0.079^{* * *}$ & 0.003 & 0.003 & 0.003 & 0.003 & $0.015^{* * *}$ & 0.001 & $0.085^{* * *}$ & - & \\
\hline VAR & $0.062^{* * *}$ & $0.080^{* * *}$ & 0.001 & 0.001 & 0.001 & 0.007 & $0.022^{* * *}$ & 0.001 & $0.079^{* * *}$ & -0.001 & - \\
\hline WGR & $0.087^{* * *}$ & $0.117^{* * *}$ & $0.023^{* * *}$ & $0.022^{* * *}$ & $0.027^{* * *}$ & $0.013^{* * *}$ & $0.015^{*}$ & $0.023^{* * *}$ & $0.105^{* * *}$ & $0.017^{* * *}$ & $0.024^{* * *}$ \\
\hline
\end{tabular}

Table 4. Mallotus villosus. Standard diversity estimates of 12 samples used. $S$ : amplification success, $A$ : average number of alleles after rarefaction, $A r$ : average number of private alleles after rarefaction, $H_{\mathrm{o}}$ : observed heterozygosity, $H_{\mathrm{e}}$ : expected heterozygosity, $F_{\text {is }}$ : Wright's inbreeding coefficient. See Table 1 for localities

\begin{tabular}{|lrccccc|}
\hline Locality & $S(\%)$ & $A$ & $A r$ & $H_{\mathrm{o}}$ & $H_{\mathrm{e}}$ & $F_{\text {is }}$ \\
\hline ABA & 99 & 11 & 0.3 & 0.682 & 0.718 & 0.050 \\
ALA & 99 & 13 & 0.7 & 0.686 & 0.718 & 0.044 \\
NFO & 100 & 12 & 0.3 & 0.681 & 0.752 & 0.094 \\
WGR & 99 & 10 & 0.4 & 0.646 & 0.721 & 0.104 \\
JMA & 97 & 12 & 0.1 & 0.628 & 0.724 & 0.133 \\
JMB & 97 & 12 & 0.2 & 0.706 & 0.777 & 0.091 \\
IFJ & 100 & 12 & 0.3 & 0.666 & 0.729 & 0.086 \\
BSW & 99 & 12 & 0.3 & 0.718 & 0.761 & 0.057 \\
BSE & 98 & 13 & 0.4 & 0.689 & 0.784 & 0.121 \\
POR & 97 & 13 & 0.3 & 0.705 & 0.757 & 0.069 \\
VAR & 97 & 12 & 0.2 & 0.690 & 0.758 & 0.090 \\
BFJ & 100 & 13 & 0.5 & 0.733 & 0.771 & 0.050 \\
& & & & & & \\
\hline
\end{tabular}

$\left(F_{\mathrm{ST}}=0.055\right.$ to 0.117$)$. Profound genetic differentiation was also observed within the Northwest Atlantic (NFO and WGR); the NFO sample was in fact significantly different from all other samples $\left(F_{\mathrm{ST}}=0.069\right.$ to 0.113 ). Considerably lower, but highly significant, $F_{\mathrm{ST}}$ values were calculated for pairwise comparisons between the West Greenland sample (WGR) and the Northeast Atlantic samples (Table 3).

Within the Northeast Atlantic, there was, in general, less heterogeneity among samples, with the peculiar exception that the 2 Jan Mayen samples (JMA and JMB) differed significantly from one another (Table 3), obscuring the genetic relationship between the Jan Mayen capelin and the other Atlantic samples. The JMA sample displayed significant $F_{\mathrm{ST}}$ values in pairwise comparisons with all other Atlantic samples. Conversely, the JMB sample, collected only $2 \mathrm{wk}$ later and in the same area, was not significantly different from any of the samples from the Barents Sea (BSE, BSW) or the 3 fjords in North Norway (BFJ, POR, and VAR), but diverged from the Svalbard sample (IFJ) (Table 3). The Svalbard sample, on the other hand, exhibited significant $F_{\mathrm{ST}}$ values when compared to the Barents Sea and Balsfjorden samples, but non-significant $F_{\mathrm{ST}}$ values when compared to the 2 fjord samples from Finnmark (POR and VAR). No significant divergence was observed among the remaining Barents Sea samples (BSE and BSW) and samples from the fjords of North Norway (BFJ, POR, and VAR).

High self-assignment success was observed for the Pacific samples (ABA and ALA) and those from the Western Atlantic (NFO and WGR) compared with samples collected in the Northeast Atlantic (Table 5). In samples showing poor self-assignment success, most individuals were assigned to neighbouring populations within the same geographical area. The principal component plot showed that the samples from the Northeast Atlantic plus the West Greenland sample clustered in one group whereas the samples from Newfoundland, Alaska and Aniva Bay were segregated (Fig. 1). Evidence that the samples could be clustered into 4 groups was provided by the hierarchical analyses in STRUCTURE and SAMOVA software (Table 6). All the Atlantic samples, with the exception of one from Newfoundland (NFO), were clustered into one group. This 4-group structure was utilised to estimate possible barriers to gene flow as illustrated in Fig. 2. There was good agreement between barriers estimated by means of the multi-locus $F_{\mathrm{ST}}$ matrix and the single-locus $F_{\mathrm{ST}}$ matrixes.

\section{DISCUSSION}

In contrast to previous population genetic studies of capelin, our samples cover the entire distributional range 
Table 5. Mallotus villosus. Percentages of correctly self-assigned individuals within each sample (bold) and individual fish assigned to other samples. Origin: actual origin of individuals sampled. See Table 1 for sample codes

\begin{tabular}{|c|c|c|c|c|c|c|c|c|c|c|c|c|}
\hline Origin & ABA & ALA & BFJ & BSE & $\overline{\text { BSW }}$ & \multicolumn{2}{|c|}{$\begin{array}{l}\text { \% individuals assigned } \\
\text { IFJ JMA }\end{array}$} & $\mathrm{JMB}$ & $\mathrm{NFO}$ & POR & VAR & WGR \\
\hline ABA & 83 & 5 & 0 & 1 & 1 & 0 & 6 & 1 & 0 & 1 & 1 & 1 \\
\hline ALA & 4 & 83 & 1 & 3 & 0 & 1 & 1 & 1 & 1 & 1 & 3 & 0 \\
\hline BFJ & 3 & 1 & 11 & 13 & 15 & 13 & 4 & 14 & 0 & 9 & 13 & 5 \\
\hline BSE & 1 & 2 & 8 & 14 & 25 & 16 & 2 & 7 & 1 & 15 & 6 & 3 \\
\hline BSW & 1 & 2 & 13 & 14 & 25 & 9 & 4 & 10 & 0 & 11 & 7 & 3 \\
\hline IFJ & 2 & 0 & 11 & 16 & 7 & 22 & 5 & 8 & 0 & 13 & 6 & 9 \\
\hline JMA & 2 & 2 & 7 & 2 & 12 & 7 & 26 & 2 & 0 & 21 & 2 & 16 \\
\hline JMB & 0 & 5 & 12 & 10 & 14 & 8 & 3 & 19 & 0 & 8 & 17 & 3 \\
\hline $\mathrm{NFO}$ & 1 & 0 & 3 & 3 & 0 & 0 & 1 & 3 & 85 & 1 & 4 & 0 \\
\hline POR & 0 & 1 & 11 & 12 & 17 & 10 & 10 & 11 & 0 & 13 & 9 & 7 \\
\hline VAR & 0 & 0 & 12 & 16 & 16 & 10 & 0 & 10 & 0 & 10 & 18 & 8 \\
\hline WGR & 0 & 0 & 8 & 6 & 8 & 8 & 10 & 4 & 0 & 8 & 6 & 40 \\
\hline
\end{tabular}

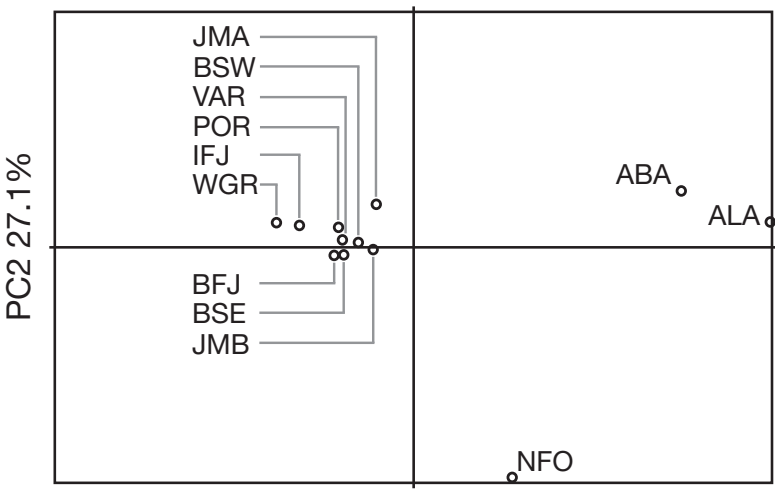

PC1 $45.1 \%$

Fig. 1. Mallotus villosus. Principal component analysis (PCA) plot of the genetic structuring among samples. PC1 and PC2 explain $45.1 \%$ and $27.1 \%$ of the total variation, respectively. Sample codes in Table 1

of the species. The microsatellite analyses clearly demonstrate that the circumpolar capelin can be divided into 4 regional groups: (1) West Pacific, (2) East Pacific, (3) Newfoundland, and (4) Northeast Atlantic and West Greenland. The structuring is supported by the various statistical tests made herein. The PCA (Fig. 1) showed that the samples from the Northeast Atlantic and West Greenland clustered into one group whereas the samples from Newfoundland, Alaska, and Aniva Bay each segregated into separate groups. The same structuring was displayed by hierarchical analyses in STRUCTURE and SAMOVA (Table 6) and by delineating possible barriers to gene flow (Fig. 2). Various genetic distance measures were used to draw UPGMA and Neighbour-Joining topologies, all displaying support of the major structure revealed by the PCA plot (authors' unpubl. data).
The genetic isolation revealed for the above populations (ABA, ALA, and NFO) was not clearly reflected by the presence of excessive numbers of private alleles. The rarefaction procedure revealed that ABA, ALA, and NFO contained an average of 0.3, 0.7, and 0.3 private alleles, respectively. In the other regional groups, the average number of private alleles per sample varied from 0.1 to 0.5 (Table 4 ). Thus, the presence of private alleles cannot be taken as evidence for population isolation in capelin. Nevertheless, there was high self-assignment success for populations ABA, ALA, and NFO (83 to $85 \%$ ), which further supports the result obtained by hierarchical analyses. The sample from West Greenland (WGR) and samples within the Northeast Atlantic showed self-assignment success ranges of 11 to $40 \%$, values which are lower than those revealed by comparisons of distinct populations of freshwater fishes (Sønstebø et al. 2007) and selected

Table 6. Mallotus villosus. Summary of combined results from STRUCTURE software for inferring $K$ populations among the 12 pooled samples (see numbering in Table 1), where the most likely grouping was estimated by 30 independent runs and tested using pairwise non-parametric Wilcoxon signed rank statistics (mean rank) and the corresponding spatial analyses of molecular variance (SAMOVA) based on allele identity $\left(F_{\mathrm{ST}}\right)$ differences at each $K$. The bold values represent situations of $K$ where $\ln \operatorname{Pr}(X \mid K)$ was greatest (lowest negative value), highest mean rank score and where the variation between groups $\left(F_{\mathrm{CT}}\right)$ was maximised and the variation within groups $\left(F_{\mathrm{SC}}\right)$ was minimised

\begin{tabular}{|llcccl|}
\hline$K$ & $\begin{array}{c}\text { Mean ln } \\
\operatorname{Pr}(X \mid K)\end{array}$ & $\begin{array}{c}\text { Mean } \\
\text { rank }\end{array}$ & $F_{\mathrm{CT}}$ & $F_{\mathrm{SC}}$ & Inferred groups \\
\hline 2 & -41779.28 & 53.78 & 0.0595 & 0.0311 & $(3),(1,2,4-12)$ \\
3 & -41609.97 & 91.52 & 0.0632 & 0.0201 & $(2),(3),(1,4-12)$ \\
4 & $\mathbf{- 4 1 5 0 5 . 5 7}$ & $\mathbf{9 6 . 6 2}$ & $\mathbf{0 . 0 6 7 8}$ & 0.0079 & $(1),(2),(3),(4-12)$ \\
5 & -41762.33 & 85.48 & 0.0633 & 0.0062 & $(1),(2),(3),(5),(4,6-12)$ \\
6 & -47658.04 & 50.10 & 0.0607 & $\mathbf{0 . 0 0 3 7}$ & $(1),(2),(3),(4),(5),(6-12)$ \\
\hline
\end{tabular}




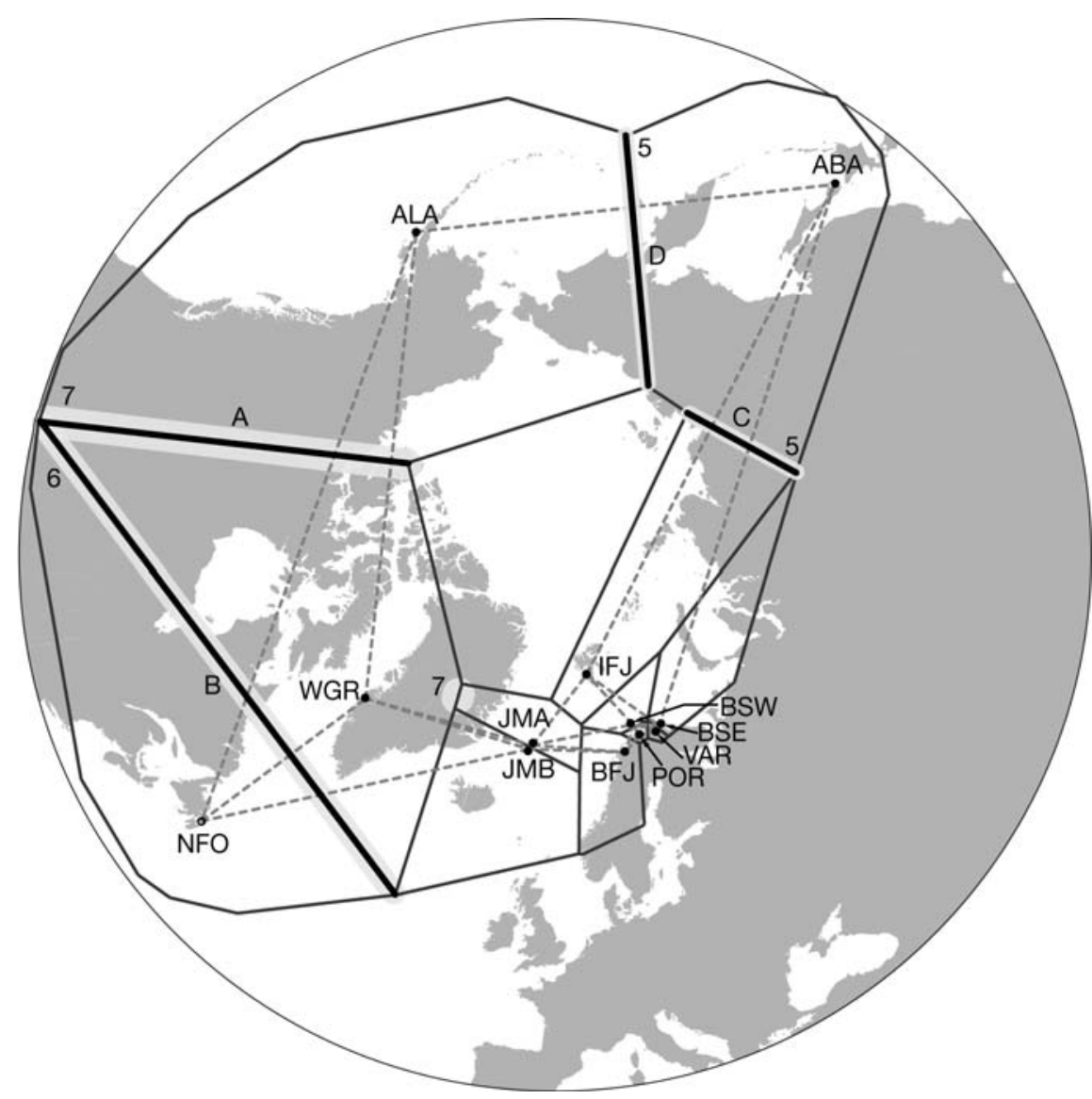

Fig. 2. Mallotus villosus. Genetic barriers to gene flow among the 12 circumpolar samples of capelin as identified by BARRIER software using the Monmonier algorithm. Dashed lines: Delauney triangulation; thin dark gray lines: Voronoi tessellation; thick black lines: barriers of gene flow revealed by the overall $F_{\mathrm{ST}}$ matrix; gray bars: 'consensus barriers' estimated from single loci $F_{\mathrm{ST}}$ matrices. Letters indicate the importance of barriers where (A) is the strongest and (D) is the weakest. Numbers and thickness of the gray bars indicate number of times the barrier appears in the calculation. Sample codes in Table 1

marine fish, e.g. Atlantic cod Gadus morhua (Nielsen et al. 2001). Our estimates, however, correspond well with recent reports on marine fishes that have a high potential for dispersal (Gilbert-Horvath et al. 2006, O'Leary et al. 2007). None of these authors suggests implicitly that the failure to correctly assign individuals to their native population arises from the biological dynamics of these species. However, the combination of highly mobile individuals and huge population sizes within a relative small geographical area must induce admixture and thus lower the success of self-assignment within each sample. The results obtained here represent an example of the suggested mechanism. All samples from North Norway (both fjord and ocean capelin) had most of their individuals assigned to neighbouring populations (compare e.g. BFJ, BSE, BSW, VAR, and POR; Table 5). The spawning grounds used by the Barents Sea capelin may shift between eastern and western locations from year to year
(Gjøsæter 1998). As a consequence, samples collected from different geographical locations in different years might comprise individuals (or offspring) originating from the same population. On the other hand, low selfassignment success by itself does not prove genetic similarity of populations. JMA and BSW had assignment estimates of 25 and $26 \%$ (Table 5), respectively, but a highly significant pairwise $F_{\mathrm{ST}}$ of 0.021 (Table 3). The majority of the individuals within each of these samples were more likely to be assigned to populations with the closest genetic resemblance. This shows that low self-assignment success does not necessarily reflect genetic homogeneity as evident from hierarchical estimates, and points to the importance of carefully inspecting the assigned individuals within each sample.

The samples analysed were collected over a period of $6 \mathrm{yr}$, close to the lifespan of capelin. We admit that the long sampling period cannot be excluded as a 
contributory factor to the structuring revealed in our samples, e.g. within the Northeast Atlantic, for reasons given above. We believe that the circumpolar genetic population structure revealed is not confounded by sampling procedures. Given the generally huge population sizes of capelin, genetic drift is also considered an unlikely contributor to the structure revealed.

\section{Genetic differentiation between the Pacific and Atlantic Oceans}

The genetic divergence revealed between capelin in the Pacific and Atlantic Oceans supports earlier morphological comparisons of the species from these 2 ocean basins (Stergiou 1989 and references therein). Although capelin is capable of long-distance migrations (Behrens et al. 2006), mixing of specimens between the 2 oceans, i.e. along the coasts of Arctic Canada and Russia seems unlikely since capelin is rarely encountered in high Arctic waters (Stergiou 1989). On the other hand, a rise in sea temperature induced by global warming is likely to extend the geographical distributional range into the Arctic (Dunbar 1983), altering the migration pattern and enhancing geneflow between the Pacific and Atlantic Oceans.

\section{Genetic differentiation within the Pacific Ocean}

Highly significant genetic divergence was detected between the samples from the eastern and western $\mathrm{Pa}$ cific Ocean, and a high assignment success for both regions indicates minimal gene flow between the populations. The hierarchical analyses (STRUCTURE and SAMOVA) and BARRIER also suggested a division of the Pacific capelin into 2 separate groups (Table 6, Fig. 2).

Capelin are distributed evenly across the Bering Sea (Brodeur et al. 1999), so dispersal between the eastern and western Pacific is possible. Other studies have reported that the lifestyle of the Pacific capelin induces a separation into populations over small and large geographical scales (Naumenko 1996, Brown 2002, Velikanov 2002). Hence, Velikanov (2002) was able to identify at least 4 reproductive units of capelin around Sakhalin Island on the basis of biological parameters and spatial distributions. Similar observations were reported by Naumenko (1996) within the western Bering Sea. Our results provide support for these earlier studies on a large geographic scale, and suggest that a more refined sampling programme is needed to resolve the genetic structure of the Pacific capelin on smaller geographic scales. In particular, sampling across the Bering Sea would provide useful information on mixing of the eastern and western Pacific capelin.

\section{Genetic differentiation within the Atlantic Ocean}

Within the Atlantic Ocean, there is little doubt that the Newfoundland capelin population is genetically differentiated from capelin in the remainder of the Atlantic Ocean. The Newfoundland capelin showed strong differentiation from the remaining part of the Atlantic Ocean in all statistical comparisons. This is in agreement with previous, but less extensive, population genetic studies (Payne 1976, Dodson et al. 1991, Birt et al. 1995, Røed et al. 2003).

Significant differentiation was observed between capelin from West Greenland and the remaining samples within the Atlantic Ocean, although the hierarchical analyses grouped this sample with capelin from the Northeast Atlantic Ocean (Table 6, Fig. 2). Capelin is abundant along most of the West Greenland coast and up to Scoresby Sound on the Greenland east coast, where mixing with the Northeast Atlantic capelin populations may occur. Allozyme analysis showed that capelin from West Greenland may be composed of several genetically distinct populations (Sørensen \& Simonsen 1988), but there is as yet no information available about the genetic relationship between capelin from West and East Greenland. However, the grouping of capelin from West Greenland with populations in the Northeast Atlantic indicates that gene flow may occur between these populations. This may be possible due to the spatial overlap between the East Greenlandic and Icelandic capelin (Friis-Rødel \& Kanneworff 2002), and also by the prevailing oceanographic features west and north of Iceland (Vilhjálmsson 2002).

The possible divergence of capelin within the Northeast Atlantic Ocean remains less conclusive. None of the hierarchical tests showed evidence for any particular genetic structuring. The samples collected within the Barents Sea and the adjacent fjords in northern Norway did not differentiate. This indicates that extensive mixing takes place either at the feeding grounds or during larval drift from the spawning sites. Hence, several fjords in northern Norway (Balsfjorden, Porsangerfjorden, and Varangerfjorden) hold capelin all year round, and they may mix with the oceanic capelin during the spawning in spring.

Interestingly, the waters around Svalbard have previously been described as a potential feeding area for the Barents Sea capelin (Gjøsæter 1998), but the present data indicate that the capelin in Isfjorden can be considered as a differentiated population. Furthermore, the significant divergence between the Isfjorden sample and the 2 samples off Jan Mayen suggests that mixing of capelin between Svalbard and the Northeast Atlantic is modest. The peculiar difference between the 2 Jan Mayen samples remains intriguing. The geo- 
graphical location of the island is such, however, that migration of capelin seems possible both from more westerly (Greenland, Denmark Strait, Iceland) and easterly populations (central Barents Sea). A comparable divergence between 2 locations around Jan Mayen was reported for the deep sea shrimp Pandalus borealis (Martinez et al. 2006), indicating the presence of different hydrographical regimes within the Jan Mayen region.

There are few other genetic studies of marine organisms in the Northeast Atlantic with a distribution comparable to that of capelin. The Iceland scallop Chlamys islandic and deep sea shrimp are benthic as adults but have long-lived planktonic larval stages. Thus, their distribution and dispersal capacity are very much dependent on passive transport by prevailing oceanographic currents, and as such compare to the early life history of capelin. Populations of C. islandica in the Northeast Atlantic were suggested to be at least partially isolated from one another, and restricted gene flow was considered a likely contributor to the observed genetic structure in allozyme frequencies (Galand \& Fevolden 2000). Populations from Iceland and Jan Mayen, together with one north of Svalbard, were more similar to one another than they were to populations from the coast of northern Norway, the central (Bear Island) and eastern (Kapp Kanin) Barents Sea. In contrast, deep sea shrimp showed no significant heterogeneity at allozymic loci in a large number of samples from within the Barents, Svalbard and Jan Mayen waters (Drengstig et al. 2000). Genetic differences were found, however, between the Norwegian fjords and the Barents Sea, probably due to restricted gene flow between fjords and the open sea (Drengstig et al. 2000). RAPD analyses of a similar sample set also showed Jan Mayen shrimp to be different from the remaining Barents Sea samples (Martinez et al. 2006). The various scenarios seen for the Iceland scallop, deep sea shrimp, and capelin, all from the same geographical region, reflect the complex interactions between the duration of planktonic stages, dispersal capacity, and oceanographic features of the Northeast Atlantic. Thus, genetic structuring of capelin within a system as complex as the Northeast Atlantic Ocean cannot be ruled out. The microsatellite data, as yet, have given only qualified support for the true nature of this structuring.

It is noteworthy that the genetic structuring of capelin was revealed only over large geographical scales and not between populations displaying different reproductive modes, i.e. beach versus ocean spawners within geographical regions. Only from North Norway did we collect samples that allowed possible comparison of genetic differentiation between beach and ocean spawners (BFJ versus BSW and BSE).
None of the statistics showed any indication of genetic divergence between those samples, providing no evidence of a genetic component to the reproductive mode. This is in accordance with earlier studies of capelin in Norwegian waters (Mork \& Friis-Sörensen 1983) and in the Northwest Atlantic Ocean (Dodson et al. 1991).

Based on mtDNA studies, Dodson et al. (1991 and Birt et al. (1995) reported a divergence between a western and an eastern clade of capelin in the Atlantic. Using an evolutionary rate of $2 \%$ nucleotide substitution per million yr (based on estimates in birds and mammals), Dodson et al. (1991) found that the 2 clades diverged 1.75 million yr ago (mya). By applying the same nucleotide substitution rate in the sequence divergence estimates obtained by Birt et al. (1995), we calculated the times of divergence to be 2.84 mya (their RFLP data) and 0.95 mya (sequencing of cytochromeb). However, divergence times obtained from molecular clocks must be considered imprecise when using estimates from other species (Pulquério \& Nichols 2007, Xu et al. 2006). Moreover, various molecular methods may differ up to 20-fold in estimates of evolutionary event timing (Pulquério \& Nichols 2007). The divergence time between the 2 suggested capelin clades (see above) varies 3 -fold. Since the data have not yet been compared with fossil records, reported time estimates of the evolutionary rate for capelin must be considered provisional, at best. Due to the effect of sequence saturation, the suggested time of divergence may be overestimated (cf. Arbogast et al. 2002). Microsatellite data have been less frequently used for estimates of molecular clocks than mtDNA. Almeida et al. (2005) presented a formula for estimating divergence time of populations based on microsatellites using the distance $\delta \mu^{2}$, which take into account the SMM. The allele permutation (see above) showed that our data follow IAM, not SMM, and is inappropriate for our data. Thus, the evolutionary history of capelin has yet to be revised.

\section{Management implications}

Capelin displays a vast phenotypic plasticity in life history traits (Stergiou 1989). However, phenotypic plasticity does not necessarily reflect genetic structuring in fishes (Conover et al. 2006). Knowledge of the genetic population structure is a prerequisite for any sustainable management of exploited fishes and a genetically based fisheries management has started to emerge e.g. for the Atlantic cod Gadus morhua (O'Leary et al. 2007, Westgaard \& Fevolden 2007). The general biology and trophic ecology of capelin are well studied (e.g. Gjøsæter 1998). This is in marked contrast 
to the genetic information, which is still scarce and fragmentary and, consequently, present management practices employed for capelin are based solely on ecological peculiarities of stocks rather than population genetic structuring (Gjøsæter 1998).

In conclusion, we present the first large-scale overview of the genetic structuring in capelin throughout its distributional range and identify 4 geographic regions each with genetically distinct populations. The development of genetic tools is growing fast and further investigations into the genetic structuring of capelin should address small-scale variations within the geographic regions we have identified and, in particular, the relationship between evolutionary process and reproductive modes, i.e. beach versus ocean spawners.

Acknowledgements. We thank A. Velikanov, M. Wilson, J. Davidsen, and J. Carscadden for providing capelin samples from Sakhalin, Alaska, Greenland, and Newfoundland. We also thank F. Manni and I. Dupanloup for valuable help with BARRIER and SAMOVA software. A. Kettunen, R. Primicerio, and 4 anonymous reviewers provided useful comments and discussion-all improving the manuscript. The study is a contribution to the BASECOEX-Programme, grant no. 140290/ 140, partly funded by the Norwegian Research Council.

\section{LITERATURE CITED}

Almeida FC, Maroja LS, Moreira MAM, Seuánez HN, Cerqueira R (2005) Population structure and genetic variability of mainland and insular populations of the Neotropical water rat, Nectomys squamipes (Rodentia, Sigmodontinae). Genet Mol Biol 28:693-699

Arbogast BS, Edwards SV, Wakeley J, Beerli P, Slowinski JB (2002) Estimating divergence times from molecular data on phylogenetic and population genetic timescales. Annu Rev Ecol Syst 33:707-740

Behrens JW, Præbel K, Steffensen JF (2006) Swimming energetics of the Barents Sea capelin (Mallotus villosus) during the spawning migration period. J Exp Mar Biol Ecol 331: 208-216

Birt TP, Friesen VL, Birt RD, Green JM, Davidson WS (1995) Mitochondrial DNA variation in Atlantic capelin, Mallotus villosus: a comparison of restriction and sequence analyses. Mol Ecol 4:771-776

Brodeur RD, Wilson MT, Walters GE, Melnikov IV (1999) Forage fishes of the Bering Sea: distribution, species associations, and biomass trends. In: Loughlin TR, Ohtani K (eds) Dynamics of the Bering Sea. University of Alaska Sea grant college program, Report 99-03, p 509-536

Brown ED (2002) Life history, distribution, and size structure of Pacific capelin in Prince William Sound and the northern Gulf of Alaska. ICES J Mar Sci 59:983-996

Carscadden JE, Vilhjálmsson H (2002) Capelin-what are they good for? ICES J Mar Sci 59:863-869

Carscadden JE, Frank KT, Miller DS (1989) Capelin (Mallotus villosus) spawning on the southeast shoal: influence of physical factors past and present. Can J Fish Aquat Sci 46:1743-1754

Christiansen JS, Siikavuopio SI (1998) Survival and growth of post-spawning capelin (Mallotus villosus) - an introduc- tory report from a laboratory study. ICES CM 1988/CC

Conover DO, Clarke LM, Munch SB, Wagner GN (2006) Spatial and temporal scales of adaptive divergence in marine fishes and the implication for conservation. J Fish Biol 69: $21-47$

> Dodson JJ, Carscadden JE, Bernatchez L, Colombani F (1991) Relationship between spawning mode and phylogeographic structure in mitochondrial DNA of North Atlantic capelin Mallotus villosus. Mar Ecol Prog Ser 76:103-113

Drengstig A, Fevolden SE, Galand PE, Aschan MM (2000) Population structure of the deep-sea shrimp (Pandalus borealis) in the North-East Atlantic based on allozyme variation. Aquat Living Resour 13:121-128

Dunbar MJ (1983) A unique international polar year contribution: Lucien Turner, capelin and climatic change. Arctic 36:204-205

Dupanloup I, Schneider S, Excoffier L (2002) A simulated annealing approach to define the genetic structure of populations. Mol Ecol 11:2571-2581

Excoffier L, Laval G, Schneider S (2005) Arlequin (version 3.0): an integrated software package for population genetics data analysis. Evol Bioinform Online 1:47-50

Fevolden SE, Pogson GH (1997) Genetic divergence at the synaptophysin (syp I) locus among Norwegian costal and North-East Arctic populations of Atlantic cod, Gadus morhua. J Fish Biol 51:895-908

Friis-Rødel E, Kanneworff P (2002) A review of capelin (Mallotus villosus) in Greenland waters. ICES J Mar Sci 59: 890-896

Galand PE, Fevolden SE (2000) Population structure of Chlamys islandica in the Northeast Atlantic-northern stocks compared with a southern relict population. Sarsia 85:183-188

Gilbert-Horvath EA, Larson RJ, Garza JC (2006) Temporal recruitment patterns and geneflow in kelp rock fish (Sebastes atrovirens). Mol Ecol 15:3801-3815

Gjøsæter H (1998) The population biology and exploitation of capelin (Mallotus villosus) in the Barents Sea. Sarsia 83: 453-496

Gordos K, Kenchington EL, Hamilton LC, Nakashima BS, Taggart CT (2005) Atlantic capelin (Mallotus villosus) tetranucleotide microsatellites. Mol Ecol Notes 5: $220-222$

Hardy OJ, Vekemans X (2002) SPAGeDi: a versatile computer program to analyse spatial genetic structure at the individual or population levels. Mol Ecol Notes 2:618-620

> Kalinowski ST (2005) HP-RARE 1.0: a computer program for performing rarefaction on measures of allelic richness. Mol Ecol Notes 5:187-189

> Manni F, Guerard E, Heyer E (2004) Geographic patterns of (genetic, morphologic, linguistic) variation: how barriers can be detected by using Monmonier's algorithm. Human Biol 76:173-190

> Martinez I, Aschan M, Skjerdal T, Aljanabi SM (2006) The genetic structure of Pandalus borealis in the Northeast Atlantic determined by RAPD analysis. ICES J Mar Sci 63: 840-850

Mork J, Friis-Sörensen E (1983) Genetic variation in capelin Mallotus villosus from Norwegian waters. Mar Ecol Prog Ser 12:199-205

Naumenko EA (1996) Distribution, biology, condition and abundance of capelin (Mallotus villosus socialis) in the Bering Sea. In: Mathisen OA, Coyle KO (eds) Ecology of the Bering Sea: a review of Russian literature. University of Alaska Sea grant college program, Report 96-01, p 237-256

Nielsen EE, Hansen MM, Schmidt C, Meldrup D, Grønkjaer P 
(2001) Fisheries: population origin of Atlantic cod. Nature 413:272

O'Leary DB, Coughlan J, Dillane E, McCarthy TV, Cross TF (2007) Microsatellite variation in cod Gadus morhua throughout its geographical range. J Fish Biol 70:310-335

Paetkau D, Slade R, Burden M, Estoup A (2004) Genetic assignment methods for the direct, real-time estimation of migration rate: a simulation-based exploration of accuracy and power. Mol Ecol 13:55-65

Payne RH (1976) Further studies on the biochemical population genetics of the capelin, Mallotus villosus: demonstration that the capelin populations of West Greenland and eastern North America are genetically distinct. CM 1976 H 24

> Piry S, Alapetite A, Cornuet JM, Paetkau D, Baudouin L, Estoup A (2004) GENECLASS2: a software for genetic assignment and first-generation migrant detection. J Hered 95:536-539

Pritchard JK, Stephens M, Donnelly P (2000) Inference of population structure using multilocus genotype data. Genetics 155:945-959

Pulquério MJF, Nichols RA (2007) Dates from the molecular clock: How wrong can we be? Trends Ecol Evol 22: 180-184

Raymond M, Rousset F (1995) Genepop (Version-1.2) - Population-genetics software for exact tests and ecumenicism. J Hered 86:248-249

Rice WR (1989) Analyzing tables of statistical tests. Evolution 43:223-225

Roby D, Lambert JD, Sevigny JM (1991) Morphometric and electrophoretic approaches to discrimination of capelin (Mallotus villosus) populations in the Estuary and Gulf of St-Lawrence. Can J Fish Aquat Sci 48:2040-2050

Røed KH, Fevolden SE, Christiansen JS, Midthjell L (2003) Isolation and characterization of DNA microsatellites for capelin Mallotus villosus population genetic studies. Mar Ecol Prog Ser 262:299-303

Ryman N, Palm S (2006) POWSIM: a computer program for assessing statistical power when testing for genetic differ-

Editorial responsibility: Konstantinos Stergiou,

Thessaloniki, Greece entiation. Mol Ecol 6:600-602

Sønstebø JH, Borgstrøm R, Heun M (2007) Genetic structure of brown trout (Salmo trutta L.) from the Hardangervidda mountain plateau (Norway) analyzed by microsatellite DNA: a basis for conservation guidelines. Conserv Genet 8:33-44

- Sørensen EF, Simonsen V (1988) Genetic differentiation among populations of capelin Mallotus villosus from the west-coast of Greenland. J Appl Ichthyology 4:23-28

Stergiou KI (1989) Capelin Mallotus villosus (Pisces: Osmeridae), glaciations, and speciation: a nomothetic approach to fisheries ecology and reproductive biology. Mar Ecol Prog Ser 56:211-224

Sunnucks P (2000) Efficient genetic markers for population biology. Trends Ecol Evol 15:199-203

> Van Oosterhout C, Hutchinson WF, Wills DPM, Shipley P (2004) MICRO-CHECKER: software for identifying and correcting genotyping errors in microsatellite data. Mol Ecol Notes 4:535-538

> Velikanov AY (2002) Spatial differences in reproduction of capelin (Mallotus villosus socialis) in the coastal waters of Sakhalin. ICES J Mar Sci 59:1011-1017

- Vilhjálmsson H (2002) Capelin (Mallotus villosus) in the Iceland-East Greenland-Jan Mayen ecosystem. ICES J Mar Sci 59:870-883

Wassmann P, Reigstad M, Haug T, Rudels B and others (2006) Food webs and the carbon flux in the Barents Sea. Prog Oceanogr 71:232-287

> Weir BS, Cockerham CC (1984) Estimating F-statistics for the analysis of population-structure. Evolution 38:1358-1370

Westgaard JI, Fevolden SE (2007) Atlantic cod (Gadus morhua L.) in inner and outer coastal zones of northern Norway display divergent genetic signature at nonneutral loci. Fish Res 85:306-315

Xu W, Jameson D, Tang B, Higgs PG (2006) The relationship between the rate of molecular evolution and the rate of genome rearrangement in animal mitochondrial genomes. J Mol Evol 63:375-392

Submitted: March 13, 2007; Accepted: November 30, 2007 Proofs received from author(s): May 5, 2008 